Do Terrorist Attacks Affect Ethnic Discrimination in the Labour Market? Evidence from Two Randomised Field Experiments

Gunn Elisabeth Birkelund Elisabeth Ugreninov Tak Wing Chan Arnfinn Midtbøen Jon Rogstad

Department of Quantitative Social Science Working Paper No. 17-02

January 2017 


\section{Disclaimer}

Any opinions expressed here are those of the author(s) and not those of the UCL Institute of Education. Research published in this series may include views on policy, but the institute itself takes no institutional policy positions.

DoQSS Workings Papers often represent preliminary work and are circulated to encourage discussion. Citation of such a paper should account for its provisional character. A revised version may be available directly from the author.

Department of Quantitative Social Science, UCL Institute of Education, University College London, 20 Bedford Way, London WC1H 0AL, UK 


\title{
Do Terrorist Attacks Affect Ethnic Discrimination in the Labour Market? Evidence from Two Randomised Field Experiments
}

\author{
Gunn Elisabeth Birkelund ${ }^{1}$, Elisabeth Ugreninov², Tak Wing Chan ${ }^{3}$, Arnfinn \\ Midtbøen $^{4}$ and Jon Rogstad ${ }^{5}$
}

\begin{abstract}
Terrorist attacks are known to influence public opinion. But do they also change behaviour? We address this question by comparing the results of two identical randomised field experiments on ethnic discrimination in hiring that we conducted in Oslo. The first experiment was conducted before the 2011 terrorist attacks in Norway; the second experiment was conducted after the attacks. In both experiments, applicants with a typical Pakistani name were significantly less likely to get a job interview compared to those with a typical Norwegian name. But the ethnic gap in call-back rates were very similar in the two experiments. Thus, Pakistanis in Norway still experienced the same level of discrimination, despite claims that Norwegians have become more positive about migrants after the terrorist attacks.
\end{abstract}

Keywords: Terrorist attack; Randomised field experiment; Ethnic discrimination

Contact Details: Tak Wing Chan (w.chan@ucl.ac.uk), Department of Social Science, UCL Institute of Education

\footnotetext{
${ }^{1}$ Department of Sociology and Human Geography, University of Oslo

${ }^{2}$ Department of Sociology and Human Geography, University of Oslo

${ }^{3}$ Department of Social Science, UCL Institute of Education

${ }^{4}$ Institute for Social Research, Oslo

${ }^{5}$ Institute for Labour and Social Research, Oslo
} 


\section{Introduction}

On 22 July 2011 Anders Behring Breivik, a far-right terrorist, detonated a car bomb at the government quarters in Oslo, killing eight people and maiming over two hundred. He then drove to the summer camp of the Workers' Youth League (Arbeidernes Ungdomsfylking), at the island of Utøya, where he shot and killed 69 people, most of whom teenagers. ${ }^{1}$ These were by far the worst terrorist attacks in modern Norwegian history. In texts that he distributed on the internet and also at his trials, Breivik identified himself as a fascist and a Nazi. He claimed that his attacks were a response to the large scale immigration to Norway of non-Europeans, especially Muslims, which he regarded as a betrayal of Norway by the political establishment.

What was the impact of Breivik's anti-Muslim, anti-immigrant attacks on Norwegian society? There is survey evidence that Norwegians became more positive about immigrants after the attack (Jakobsson and Blom, 2014). But did the attacks also change behaviour? Specifically, did ethnic minorities experience less discrimination in the labour market after the attacks? In this paper we address this question by comparing two identical randomised field experiments on ethnic discrimination in hiring that we conducted in Oslo. The first experiment was conducted before the attacks in the fall of 2010; the second experiment was conducted afterwards in the fall of 2011.

\subsection{Terrorist attacks and public opinion}

There is some evidence that terrorist attacks could change public opinion. For example, Traugott et al. (2002) argue that after 9/11 ethnic groups of Middle Eastern origins are viewed less favourably in America than those of African, Hispanic, Asian or European descent. Huddy et al. (2002, p. 426) show that 9/11 'increased the willingness [of Americans] to forgo civil liberties, boosted confidence in the government's ability to prevent terrorism in the United States, and increased support for the use of ground troops in attacks against terrorists.'

Using data from a small student sample from the Netherlands, Boomgaarden and de Vreese (2007) suggest that after the murder of Theo van Gogh by a Muslim extremist in 2004, respondents were more likely to

\footnotetext{
${ }^{1}$ The Workers' Youth League is affiliated to Labour Party, which was then the governing party of Norway. Breivik targeted this camp because many of the participants were young activists and potential future Labour politicians.
} 
see immigrants as a security threat, or to see the religious practice of the migrant communities as a threat to the Dutch way of life. Similarly, Echebarria-Echabe and Fernández-Guede (2006) maintain that after the Madrid bombing in 2004, there was an increase in anti-Arab prejudice and antisemitism, an increase in authoritarianism, and a drop in support for liberal values. ${ }^{2}$

As noted already, Jakobsson and Blom (2014, p. 482) show that Norwegian's 'attitudes toward immigrants became more positive after the [Breivik] attacks. The size of the effect is not large but it is three times as high as the gender gap in attitudes towards immigrants.' Wollebæk et al. (2012, p. 32) use data from two web surveys and show that after the Breivik attacks there was an increase in Norway in 'interpersonal and institutional trust as well as a modest increase in civic engagement, especially among youth.'

The impact of terrorist attacks can be felt far beyond the country in which they took place. Noelle-Neumann (2002) reports that after 9/11 Germans became more supportive of new legislation to limit immigration (see also Schüller, 2016). Åslund and Rooth (2005, p. 605) show that Swedish public opinion towards immigrants became more negative after 9/11. Legewie (2013) compares European Social Survey (ESS) respondents interviewed a week after the 2002 Bali attacks with those interviewed in the 30 days previously. He shows that in Portugal, Poland and Finland, post-attack ESS respondents were significantly more negative about immigrants. Furthermore, using a multilevel model, he shows that the impact of the Bali bombings on attitudes is more pronounced in regions where unemployment rates were rising, and less pronounced if the respondent had personal contact with migrants. Because the timing of the Bali attacks was exogenous to the survey, Legewie argues that the Bali attacks were a natural experiment, and the pre-attack/post-attack comparison can be interpreted as a measure of the causal impact of the Bali attacks on public opinion.

Overall, there is considerable evidence that terrorist attacks could change public opinion. But several questions remain. First, the 9/11 attacks, the bombings in Bali and Madrid, and the murder of Theo Van Gogh, etc. were carried out by Jihadists purporting to act in the name of Islam. It is perhaps unsurprising that these acts could reinforce existing prejudice against immigrants and minorities, especially Muslims. But could a far-right terrorist attack have the opposite effect? Lieberson (1985, p. 69) argues that many causal processes are asymmetrical and it is fallacious to think that '[i]f a

\footnotetext{
${ }^{2}$ It is not clear to us how Echebarria-Echabe and Fernández-Guede (2006) sampled their 206 respondents, nor of which population they are a sample.
} 
change in $X$ makes $Y$ change in a certain direction, then surely the opposite change in $X$ would generate an opposite change in $Y$.' So it is not clear that the Breivik attacks have reduced xenophobia or Islamophobia in Norway.

Secondly, how durable are the changes? Public opinion can be quite fickle, and the impact of terrorist attacks on public opinion might not last very long (Sorrentino and Vidmar, 1974). Indeed, Huddy et al. (2002, p. 426) note that 'the power and impact of the [9/11] attacks declined somewhat over time.' Hopkins (2010, p. 51) uses panel data to show 'marked but shortlived effects of September 11' on attitudes regarding migrants. In a similar vein, Jacobs et al. (2011, p. 341) show that 'complaints about antisemitism in Belgium indeed showed a statistically significant increase during the Israeli military operation Cast Lead ... [but] this effect was not lasting and wore off after a couple of weeks.' Clearly, transient changes are of less significance than long-lasting ones. Most of the studies cited above use data that cover just a few weeks (in some cases, days) before or after a terrorist attack. It would be important to evaluate the impact of terrorist attacks over a longer period.

Thirdly, talk is cheap. It is not clear that terrorist attacks have the same impact on behaviour as on public opinion. As noted above, Åslund and Rooth (2005) use survey data to show that Swedes became more negative about immigrants after 9/11. In the same paper, they also use Swedish register data to examine unemployment exit rates and find no difference between ethnic groups, i.e. there is 'no sign of increased discrimination toward these minorities' (Åslund and Rooth, 2005, p. 603). This inconsistency between attitudes and behaviour echoes the finding of LaPiere (1934) who travelled across the US in the 1930s with a Chinese couple. He reported that 'in only one out of 251 instances in which we purchased goods or services [from restaurants and hotels] necessitating intimate human relationships did the fact that my companions were Chinese adversely affect us' (LaPiere, 1934, p. 233). Six months later, he sent a questionnaire to the hotels and restaurants visited, asking them to indicate whether they would accept Chinese guests. Over 90\% replied no. In other words, the very widespread antipathy and discriminatory attitudes towards Chinese in the US in the 1930s were rarely matched by actual discriminatory behaviour, at least of the kind studied in that paper. Whatever methodological criticisms we might have about Åslund and Rooth (2005) or LaPiere (1934), ${ }^{3}$ it is plainly unwarranted to make inference about behavioural change on the basis of attitudinal data alone. Direct behavioural

\footnotetext{
${ }^{3}$ See, for example, Ajzen et al. (1970) for a critique of LaPiere (1934).
} 
evidence of ethnic discrimination would be needed. ${ }^{4}$

\section{The Norwegian context}

Norway has seen a steady flow of net immigration since the 1970s. First and second generation immigrants accounted for $1.5 \%$ of the population in 1970, rising to $11.4 \%$ in 2010 (Andreassen and Dzamarija, 2011, p. 16). The scale and the nature of immigration to Norway as well as the country of origin of the migrants have changed over time. In particular, with the enlargement of the European Union in 2004, Poles have become the largest migrant group. The largest non-European migrant groups are the Iraqis and the Somalis who came to Norway as refugees over the past decade.

But the most established non-European migrant community in Norway is the Pakistanis. Young Pakistani men first came to Norway as guest workers in the late 1960s. They were soon joined by their family, and many had brought up children in their adopted country. Indeed, second generation Pakistanis is the largest group of Norwegians born to immigrant parents (Andreassen and Dzamarija, 2011, p. 22, Table 2.1.1); the vast majority of whom attended school in Norway. And since many Norwegian-born children of Pakistani migrants are now in their 20s and 30s, they are either economically active or about to enter the labour market. Andreassen et al. (2013, p. 16) report that ' 83 per cent of the immigrants with a background from Pakistan [live] in Oslo and Akershus [the county neighbouring Oslo], and 67 per cent in Oslo alone.' Oslo itself is quite a diverse city: $27 \%$ of its residents are first or second-generation immigrants of one or another heritage (Andreassen and Dzamarija, 2011, p. 15).

Compared to other Europeans, Norwegians seem relatively positive about immigration. Based on the 2002 European Social Survey (ESS) data, Blom (2011b, p. 151) places Norway 'in the liberal or "immigrantfriendly" third of the participating countries in the European Social Survey' (see also Sides and Citrin, 2007). The ESS module on attitudes towards immigration has been repeated in 2014. Using this new data set, Heath

\footnotetext{
${ }^{4}$ There is, however, some evidence that terrorist attacks might change demographic behaviour. For example, Nakonezny et al. (2004) argue that the 1995 Oklahoma City bombing lowered divorce rates in Oklahoma, and Rodgers et al. (2005) argue that the same event raised fertility rates in Oklahoma. Similarly, Hansel et al. (2011) argue that 9/11 reduced the divorce rates in the 62 counties in New York. Also, Hernæs (2015, p. 24) uses Norwegian register data and shows that 'sickness absence rates declined substantially in municipalities affected more intensely by the [Breivik] attack.'
} 
and Richards (2016, p. 1, Figure 1) show that Norway ranks third out of twenty (after Sweden and Denmark) in the proportion of respondents who think that their country is made a better place to live as a result of migration. Analysing survey data collected by Statistics Norway, Blom (2011a, p. 133) reports that in 2009 '[s]even out of 10 [Norwegians] appreciate immigrants' culture and labour efforts and believe that labour immigration from non-Nordic countries makes a positive contribution to Norwegian economy.' Moreover, about $90 \%$ think that 'all immigrants should have the same job opportunities as Norwegians' (Blom, 2011a, p. 135, Tables 6.1 and 6.2). Having said that, the same survey also shows that '[t]hree out of 10 suspect that immigrants abuse the social welfare system, and 1 out of 3 believe immigrants represent a source of insecurity' (Blom, 2011a, p. 133).

Immigrant children or children born to immigrant parents achieve lower scores in most national tests (Nygård, 2011, p. 50). They also have lower educational attainment. In 2009, '40 per cent of the population aged 16 years and older had attained upper secondary education, and 25 per cent had attained tertiary level of education (Nygård, 2011, p. 59). For firstgeneration immigrants of the same age, the corresponding figures were $17 \%$ and $18 \%$. As regards second-generation migrants, $30 \%$ had upper secondary qualifications, and $17 \%$ had tertiary qualifications.

Immigrants also have lower level of employment than the population at large, though there is large variation by country of origin. In particular, the employment rates of migrants from the new EU countries in Eastern Europe are comparable to the overall rate, while the employment rates of Somalis, Iraqis and Afghans, who came to Norway mainly as refugees, are lower. Pakistanis also have a relatively low employment rate. But two features of their employment pattern stand out. First, there is a very large gender gap, with Pakistani men being twice as likely to be economically active as Pakistani women (61\% vs $31 \%)$. Secondly, Pakistanis have the highest rate of self-employment of all ethnic groups in Norway (Olsen, 2011).

It is also relevant to note that although the global economy has been in turmoil since the 2008 financial crisis, the Norwegian labour market has been relatively robust and stable over this period. The left panel of Figure 1, which is based on register data supplied to us by Statistics Norway, reports the employment rate of young people (aged 23 to 30 ) in the Oslo area between 2008 and 2012. It can be seen that there was an initial drop from $80 \%$ in 2008 to $78 \%$ in 2009 . Since then the overall employment rate of young people in Oslo fluctuated narrowly between $77 \%$ and $78 \%$. As already noted, immigrants of non-Western origin tended to have lower em- 

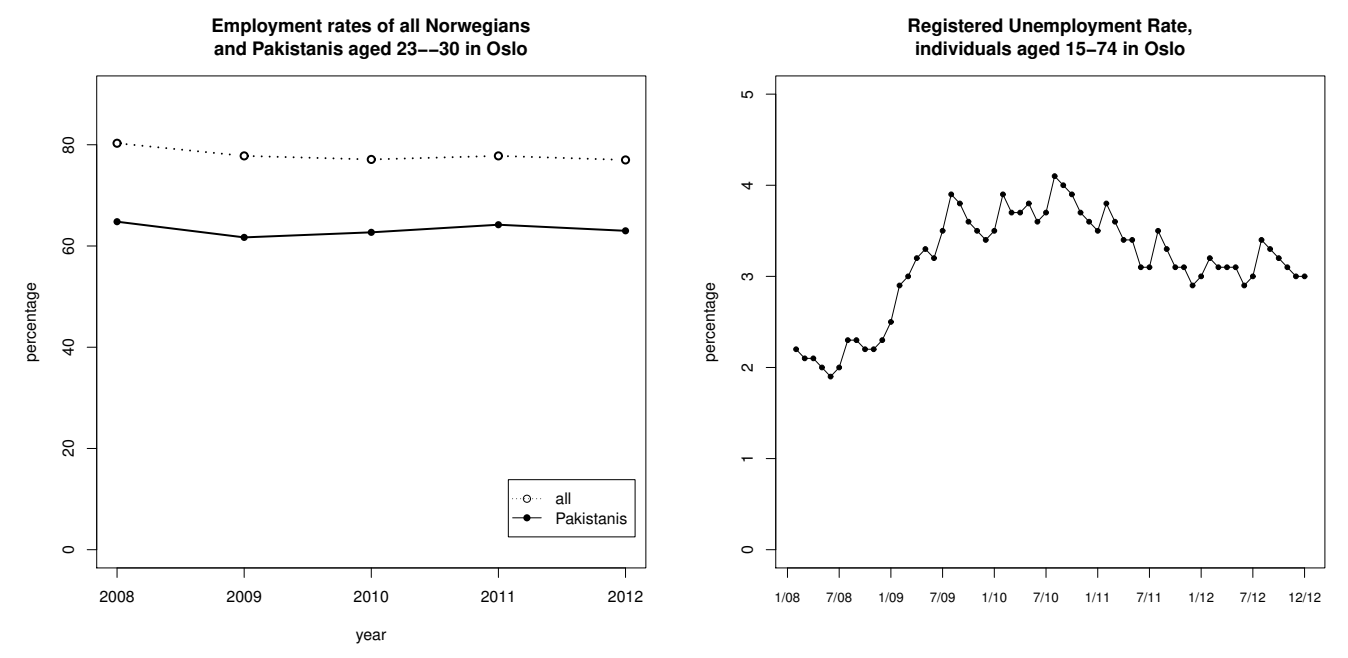

Figure 1: Labour market condition in Oslo, 2008-2012

ployment rates. The left panel of Figure 1 shows that the employment level of young Pakistanis in Oslo, while also broadly stable during this period, was consistently about $15 \%$ below the overall rate.

The right panel of Figure 1, which plots the monthly unemployment rate in the Oslo metropolitan area between 2008 and 2012, offers an alternative take on the condition of the labour market. ${ }^{5}$ It can be seen that in the first half of 2008 unemployment in Oslo was at a very low level, at about $2 \%$. The rate of unemployment rose sharply afterwards, reaching a peak of about $4 \%$ in mid-2010. This was twice as high as the pre-crisis level, but still relatively modest by international standard. Since then the unemployment rate has been falling, stabilising at about the 3\% level in 2012. Recall that our two experiments were conducted in 2010 and 2011 respectively. This means that the first experiment took place at a time when the labour market was relatively loose, and the second experiment was conducted while the labour market was tightening.

\footnotetext{
${ }^{5}$ The unemployment rates are based on the number of unemployed persons registered at the employment office. Unfortunately, this publicly downloadable time series (see www.ssb.no/statistikkbanken, series 04471) refers to individuals aged 15 to 74 and it is not broken down by ethnicity.
} 


\section{Field experiment procedure}

Our data come from two identical randomised field experiments that we conducted in Oslo. In the first experiment, which was run from September to November 2010 (i.e. some eight to ten months before the Breivik attacks), we sampled 450 job openings and sent out 900 fictitious CVs and cover letters. The second experiment was run from October to December 2011 (i.e. three to five months after the attacks), in which we sent out 576 fictitious applications in response to 288 job postings. ${ }^{6}$

In both experiments, we sampled job vacancies posted on the main recruitment websites in Norway. ${ }^{7}$ In principle, all job openings in the Oslo area were included in the study, provided that they fell in the following six broad categories ('health service', 'accounting and insurance', 'public consultants', 'primary and preschool teaching', 'transport and storage', and 'ICT and communication'). But we limit ourselves to one job opening per employer, except for large organisations which have separate recruitment personnel for different departments.

We included in our experiments low-skilled and semi-skilled jobs (e.g. warehouse workers and auxiliary nurses) as well as jobs that require higher education (e.g. nurses, teachers, financial accountants, and public consultants). In line with the prevailing pattern of occupational sex segregation, the fictitious applicants for openings in female-dominated occupations (e.g. nurses or social workers) were female. The opposite holds for openings in male-dominated occupations (e.g. transportation and warehouse workers). Where the occupations are gender-integrated (e.g. financial services, teaching, and public administration), the fictitious applicants could be either male or female.

The fictitious job applicants were all 25 years old. Within each pair, the two applicants have the same educational credentials and work experience. We wrote their CVs and cover letters, in fluent Norwegian, in such a way that they always meet the formal requirements listed in the job advertisements. Furthermore, the CVs report educational qualifications earned in Norwegian schools and colleges and work experience in Norwegian firms, indicating to the employer that the minority applicant was either born in Norway or migrated to Norway at a young age. To avoid suspicion, the two CVs and cover letters within each pair have different fonts, and the qualifications are listed in different order. The only material

\footnotetext{
${ }^{6}$ Both field experiments are approved by The National Committee for Research Ethics in the Social Sciences and the Humanities (NESH).

${ }^{7}$ The two websites were www. finn. no and www.nav.no.
} 
difference between the two applicants was their name, which was either a typical Pakistani name or a typical Norwegian name. ${ }^{8}$ Because the names were randomly assigned to the documents, there should not be any systematic difference, observed or otherwise, between the two groups of applicants except their ethnicity as signalled by their names. As a result, any significant between-group difference in call-back rate can reasonably be interpreted as evidence of discrimination. ${ }^{9}$

The CVs and cover letters were sent from the fictitious applicants' email addresses or uploaded to the recruitment websites. Each applicant had a real cell phone number and email address, as well as a fictitious postal address, and these contact details were listed on their CV. Employers contacting the applicants on cell phones were directed to a personal voice mail message which, in fluent Norwegian, stated the name of the applicant and encouraged the caller to leave a message with contact information. The research team monitored all voice mails and emails at least once a day. When the applicants received invitations for job interviews, the responses were carefully registered. After registration, the call-backs were politely declined by text message or email (depending on how the employer contacted the applicants). ${ }^{10}$

Importantly, a call-back is not necessarily a job interview offer. For example, employers may want to let the applicants know that they are not suitable for a job. To avoid potential misinterpretation, employers who left an ambiguous message asking the applicant to call back received a text message or an email to determine whether the call was really a job interview offer. In the vast majority of cases, this was indeed the case, and the employers' response was registered appropriately.

\section{Results}

Table 1 reports some descriptive statistics of the two experiments. By design, exactly one half of the fictitious applicants had Norwegian names and the other half had Pakistani names. In both experiments, about half

\footnotetext{
${ }^{8}$ Typical Pakistani names used in the experiment were Kamran Ahmed, and Saera Rashid; typical Norwegian names were Andreas Hansen and Ida Johansen.

${ }^{9}$ Field experiments, especially audit studies in which pairs of actors are sent to attend interviews, are not without their critics, see e.g. Heckman (1998) and Neumark (2012), and see Pager (2007) for a response.

${ }^{10}$ Because the mail addresses were fictitious, any attempts by employers to contact the applicants by post could not be recorded, but earlier research has suggested that very few employers contact applicants by post (Bertrand and Mullainathan, 2004, p. 997).
} 
Table 1: Descriptive statistics (percentages)

\begin{tabular}{lrrr}
\hline \hline & 2010 & 2011 & overall \\
\hline Norwegian & 50.0 & 50.0 & 50.0 \\
Pakistani & 50.0 & 50.0 & 50.0 \\
\hline female & 47.6 & 51.1 & 48.9 \\
male & 52.4 & 48.9 & 51.1 \\
\hdashline pubilic sector & 70.0 & 71.4 & 70.5 \\
private sector & 30.0 & 28.6 & 29.5 \\
\hline health service & 10.7 & 13.7 & 11.8 \\
accounting \& insurance & 27.3 & 24.8 & 26.4 \\
public consultant & 8.0 & 9.4 & 8.5 \\
primary/preschool teaching & 19.1 & 15.5 & 17.7 \\
transport \& storage & 12.2 & 16.6 & 13.9 \\
ICT \& communication & 22.7 & 20.1 & 21.7 \\
\cline { 1 - 3 } calli-back & 32.3 & 45.1 & 37.2 \\
no call-back & 67.7 & 54.9 & 62.8 \\
\hline$N$ & 900 & 556 & 1456 \\
\hline \hline
\end{tabular}

of the fictitious applicants were women, and about $70 \%$ of the applications were sent to public sector employers. The distributions of openings by industrial sector were broadly comparable across the two studies. But the most notable thing of Table 1 is that the overall call-back rate was considerably higher in 2011 (45\%) than in 2010 (32\%). This might to some degree reflect the falling unemployment rate during the second fieldwork period (see the right panel of Figure 1).

Figure 2 reports the bivariate associations between call-back rate and the covariates. In both 2010 and 2011 applications sent ostensibly by female applicants or those sent to private sector employers were more likely to get a call-back. Call-back rates also varied widely by industrial sectors. In $2010,72 \%$ of the applications for openings in teaching, but only $8 \%$ of those for openings in public consultancy, resulted in a job interview offer. Figure 2 also shows that, with the exception of 'transport and storage' the rank order of the call-back rates by industry was the same in both years.

Let us turn to the ethnic gap in call-back rate. In the first experiment, $38 \%$ of applicants with Norwegian names received a call-back, compared to $26 \%$ of applicants with Pakistani names. This $12 \%$ gap represents strong evidence against the null hypothesis of no ethnic difference in callback rates (s.e. $=.031, z$-score $=3.78, p=.0002$, two-tailed test). Put differently, on average, white Norwegians need to apply for three jobs to get 


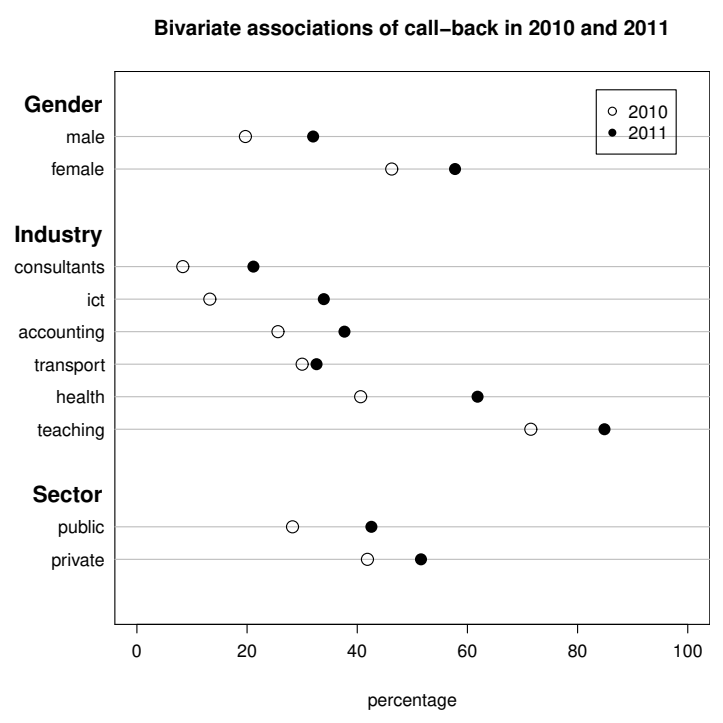

Figure 2: Call-back rates in 2010 and 2011 by covariates

a job interview. The corresponding number for Pakistanis is four. This is evidence of ethnic discrimination at this initial stage of the hiring process. It is worth comparing our results with those of Bertrand and Mullainathan (2004, p. 998) who show that in Boston and Chicago 'a White applicant should expect on average one callback for every 10 ads she or he applies to; on the other hand, an African-American applicant would need to apply to about 15 different ads to achieve the same result.'

As noted above, the call-back rate in the second experiment was considerably higher for both groups of applicants, with $51 \%$ of those with Norwegian names and $40 \%$ of those with Pakistani names getting a callback for job interview. Again, this gap of $11 \%$ speaks strongly against the null hypothesis of no ethnic difference in 2011 (s.e. $=.042, z$-score $=2.64$, $p=.0008$, two-tailed test). Figure 3 reports these results graphically. It is clear that in both randomised field experiments applicants with Pakistani names were at an disadvantage compared to those with Norwegian names.

Columns 1 and 3 of Table 2 report the regression coefficients of a linear probability model. The dependent variable is whether the applicant was called back for a job interview. In the two studies, having a Pakistani name lowers the call-back rate by 12 and 11 percent respectively. This is of course the same results reported above. ${ }^{11}$ Columns 2 and 4 of Table 2

\footnotetext{
${ }^{11}$ We use robust standard errors in these regressions to take into account the fact that
} 


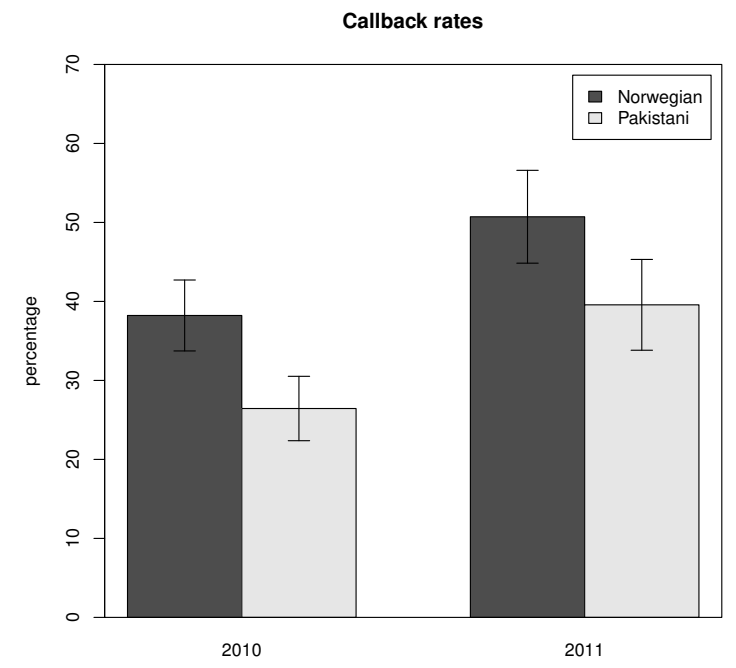

Figure 3: Callback rates (with 95\% confidence intervals) for Norwegians and Pakistanis in 2010 and 2011

then show that controlling for the other characteristics of the applications (i.e. the six industry categories, the gender of the fictitious applicant, and whether the job was in the public or private sector) does not change the estimated adverse effect of having a Pakistani name.

For our present purpose, the question of interest is whether job applicants with Pakistani names experienced less discrimination in the wake of the Breivik attacks. As noted earlier, the Norwegian-Pakistani gap in call-back rate of the two experiments were 12\% in 2010 and $11 \%$ in 2011. Given how similar these figures are, it seems fair to say that not much has changed. We can compare the gaps more formally by pooling data from the two experiments. Column 5 shows that, averaging over the two experiments, compared with applicants with Norwegian names, those with Pakistani names were about $12 \%$ less likely to be offered a job interview. It also shows that call-back rate was about 13\% higher in 2011 compared to 2010. Column 6 includes an interaction term between having a Pakistani name and being in the 2011 experiment. This is the key parameter gauging whether the level of discrimination was different in the two experiments. As it turns out, there is really no evidence that this parameter is significantly different from zero. Conversely put, there is no evidence that

we sent two applications to each job vacancy. We also obtain broadly the same results if we fit the data with probit models rather than linear probability models. Details are available from the authors on request. 
Table 2: Regression coefficients of linear probability models predicting the probability being called back for job interview

\begin{tabular}{|c|c|c|c|c|c|c|c|}
\hline & \multicolumn{2}{|c|}{2010} & \multicolumn{2}{|c|}{2011} & \multicolumn{3}{|c|}{ pooled 2010/2011 } \\
\hline & 1 & 2 & 3 & 4 & 5 & 6 & 7 \\
\hline Pakistani & $\begin{array}{c}-.117 * * \\
(.017)\end{array}$ & $\begin{array}{c}-.117 * * \\
(.017)\end{array}$ & $\begin{array}{c}-.111 * * \\
(.025)\end{array}$ & $\begin{array}{c}-.111 * * \\
(.025)\end{array}$ & $\begin{array}{c}-.115 * * \\
(.014)\end{array}$ & $\begin{array}{c}-.117 * * \\
(.017)\end{array}$ & $\begin{array}{c}-.117 * * \\
(.017)\end{array}$ \\
\hline 2011 & & & & & $\begin{array}{l}.128 * * \\
(.033)\end{array}$ & $\begin{array}{l}.124 * * \\
(.037)\end{array}$ & $\begin{array}{l}.133 * * \\
(.034)\end{array}$ \\
\hline $\begin{array}{l}\text { Pakistani } \times \\
2011\end{array}$ & & & & & & $\begin{array}{l}.006 \\
(.030)\end{array}$ & $\begin{array}{l}.006 \\
(.030)\end{array}$ \\
\hline male & & $\begin{array}{c}-.034 \\
(.051)\end{array}$ & & $\begin{array}{c}-.084 \\
(.077)\end{array}$ & & & $\begin{array}{l}-.052 \\
(.043)\end{array}$ \\
\hline private sector & & $\begin{array}{l}.008 \\
(.054)\end{array}$ & & $\begin{array}{r}-.085 \\
(.067)\end{array}$ & & & $\begin{array}{l}-.025 \\
(.042)\end{array}$ \\
\hline $\begin{array}{l}\text { accounting \& } \\
\text { insurance }\end{array}$ & & $\begin{array}{c}-.126 \\
(.086)\end{array}$ & & $\begin{array}{c}-.252 * \\
(.101)\end{array}$ & & & $\begin{array}{c}-.176 * * \\
(.065)\end{array}$ \\
\hline public & & $-.308 * *$ & & $-.364 * *$ & & & $-.333 * *$ \\
\hline consultant & & $(.085)$ & & $(.111)$ & & & $(.068)$ \\
\hline primary & & $.309 * *$ & & $.226 * *$ & & & $.272 * *$ \\
\hline preschool & & $(.079)$ & & $(.086)$ & & & $(.059)$ \\
\hline transport \& & & -.066 & & $-.262 *$ & & & -.153 \\
\hline storage & & $(.103)$ & & $(.125)$ & & & $(.079)$ \\
\hline ICT \& & & $-.236 *$ & & $-.248 *$ & & & $-.248 * *$ \\
\hline communication & & $(.093)$ & & $(.116)$ & & & $(.072)$ \\
\hline constant & $\begin{array}{l}.382 * * \\
(.022)\end{array}$ & $\begin{array}{l}.459 * * \\
(.075)\end{array}$ & $\begin{array}{l}.507 * * \\
(.030)\end{array}$ & $\begin{array}{l}.727 * * \\
(.080)\end{array}$ & $\begin{array}{l}.381 * * \\
(.022)\end{array}$ & $\begin{array}{l}.382 * * \\
(.022)\end{array}$ & $\begin{array}{l}.515 * * \\
(.057)\end{array}$ \\
\hline$R^{2}$ & .015 & .218 & .012 & .180 & .030 & .030 & .211 \\
\hline
\end{tabular}

${ }^{\star} p<.05,{ }^{* *} p<.01$; reference category for industrial sectors is 'health service'; standard errors in parentheses. 


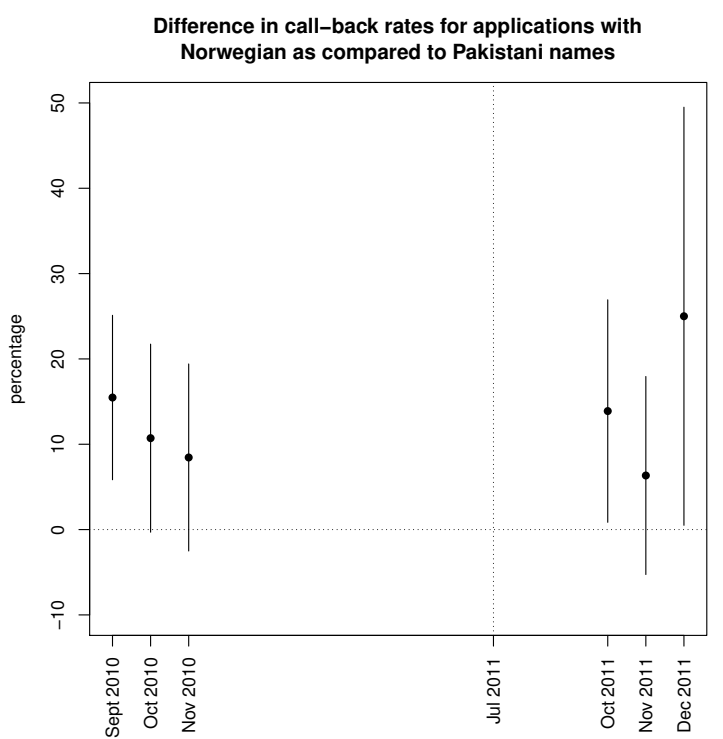

Figure 4: Ethnic gap in call-back rates by month

the Breivik attacks had lowered the level of discrimination experienced by job applicants with Pakistani names. In column 7, we show that controlling for covariates does not change the main result.

Finally, does the magnitude of the ethnic gap in the second experiment varies with time lapsed since the Breivik attacks? To address this question, we group the applications by the month in which they were sent out, and compute the ethnic gap for each month. Because of the smaller $N$ in each month's data, the relevant confidence intervals are much wider. But we are not primarily concerned with statistical significance here. Rather, we are interested in detecting possible temporal pattern. For completeness, we also plot the ethnic gap by month for applications sent in the first experiment.

Because the second experiment did not begin until October 2011, we simply do not have any data on the level of ethnic discrimination in the immediate aftermath of the Breivik attacks. But Figure 4 shows that the ethnic gap in October 2011 was already at the 2010 level. That is to say, even if we assume that Breivik had an impact on the levels of ethnic discrimination in August and September 2011, this effect had entirely disappeared by October. Moreover, the last three data points of 2011 do not show that any systematic trend in the size of the ethnic gap. 


\section{Summary and discussion}

In this paper, we compare the results of two identical randomised field experiments on ethnic discrimination in hiring that we conducted in Oslo. The first experiment was conducted 8 to 10 months before the terrorist attacks of 2011; the second was conducted 3 to 5 months after the attacks. In the two experiments, applicants with a typical Pakistani name were $12 \%$ and $11 \%$ respectively less likely to get a job interview than those with a typical Norwegian name. This is clear evidence that ethnic discrimination exists, at this initial stage of hiring, in liberal and immigrant-friendly Norway. But there is no evidence that Pakistanis experienced a lower level of discrimination in the second experiment. This finding stands in contrast to survey evidence of Norwegians becoming more positive about immigrants after the Breivik attacks. Indeed, our finding is inconsistent with the sizeable literature of terrorist attacks having an impact on attitudes about migrants and minorities.

How do we understand the results? Because Breivik is a far-right terrorist, the atrocities that he perpetuated were, in one sense, quite different from most of the other terrorist attacks considered in the literature. It might be the case that Jihadist attacks could reinforce existing xenophobia or Islamophobia and lead to higher levels of discrimination against minorities or immigrants; but a far-right attack is not powerful enough to overcome existing prejudice and discrimination. While possible, existing evidence is not entirely supportive of this interpretation. Recall that Åslund and Rooth (2005, p. 603) also find 'no sign of increased discrimination towards ... minorities' after 9/11. It is true that Aslund and Rooth (2005) is based on observational rather than experimental data. But their finding does challenge the view that Jihadist attacks would change the level of discrimination.

Another interpretation is that the Breivik attacks had led to some behavioral changes. But these changes were very shortlived, and after a couple of months people's behaviour had returned to the pre-attack level. We do not have data to test one part of this interpretation (namely that there is an initial impact); but the other part (the transience of the impact) is consistent with our data. However, if this interpretation holds good, we should be wary of overstating the impact of terrorist attacks on society.

Finally, it might be the case that the Breivik attacks had brought about relatively lasting attitudinal change regarding ethnic minorities in the general population, but this has not (yet) percolated through to the hiring behaviour of employers or HR managers. In their review of the literature on 
the attitude-behaviour link, Fazio and Roskos-Ewoldsen (2005, p. 44) note that 'the answer to the question "Is there a relation between attitudes and behavior?" is a resounding "sometimes".' They point out that the strength of the attitudes-behaviour link depends on a host of factors, including how attitudes and behaviour are specified, the strength of the relevant social norms, whether the attitude is based on direct experience, the time pressure individuals were put under when they acted, and so on. This interpretation is also consistent with our data. But, again, if true, we should be wary of claims that terrorist attacks have behavioural impact on the majority-minority relationships in society.

\section{References}

Ajzen, I., Darroch, R. K., Fishbein, M., and Hornik, J. A. (1970). Looking backward revisited: a reply to Deutscer. American Sociologist, 5(3), 267-273.

Andreassen, K. K. and Dzamarija, M. T. (2011). Population. In K. Henriksen, L. Østby, and D. Ellingsen, editors, Immigration and immigrants 2010, Statistical Analyses, chapter 2, pages 15-46. Statistics Norway, Oslo.

Andreassen, K. K., Dzamarija, M. T., and Slaastad, T. I. (2013). Large diversity in little Norway. Samfunnsspeilet, 5, 11-19.

Åslund, O. and Rooth, D.-O. (2005). Shifts in attitudes and labor market discrimination: Swedish experiences after 9-11. Journal of Population Economics, 18, 603-629.

Bertrand, M. and Mullainathan, S. (2004). Are Emily and Greg more employable than Lakisha and Jamal? A field experiment on labor market discrimination. American Economic Review, 94(4), 991-1013.

Blom, S. (2011a). Attitudes towards immigrants and immigration. In K. Henriksen, L. Østby, and D. Ellingsen, editors, Immigration and immigrants 2010, chapter 6, pages 133-147. Statistics Norway, Oslo.

Blom, S. (2011b). Comparison of attitudes in Norway and other European countries. In K. Henriksen, L. Østby, and D. Ellingsen, editors, Immigration and immigrants 2010, chapter 7, pages 151-167. Statistics Norway, Oslo. 
Boomgaarden, H. G. and de Vreese, C. H. (2007). Dramatic real-world events and public opinion dynamics: media coverage and its impact on public reactions to an assassination. International Journal of Public Opinion Research, 19(3), 354-366.

Echebarria-Echabe, A. and Fernández-Guede, E. (2006). Effects of terrorism on attitudes and ideological orientation. European Journal of Social Psychology, 36, 259-265.

Fazio, R. H. and Roskos-Ewoldsen, D. R. (2005). Acting as we feel: when and how attitudes guide behavior. In T. C. Brock and M. C. Green, editors, Persuasion: Psychological Insights and Perspectives, chapter 5, pages 41-62. Sage, Thousand Oaks, CA.

Hansel, T. C., Nakonezny, P. A., and Rodgers, J. L. (2011). Did divorces decline after the attacks on the World Trade Center? Journal of Applied Social Psychology, 41(7), 1680-1700.

Heath, A. and Richards, L. (2016). How do europeans differ in their attitudes to immigration? Centre for Social Investigation, Nuffield College, Oxford.

Heckman, J. J. (1998). Detecting discrimination. Journal of Economic Perspectives, 12(2), 101-116.

Hernæs, Ø. (2015). Essays in Applied Microeconomics. Ph.D. thesis, European University Institute, Florence.

Hopkins, D. J. (2010). Politicized places: explaining where and when immigrants provoke local opposition. American Political Science Review, 104(1), 40-60.

Huddy, L., Khatib, N., and Capelos, T. (2002). Reactions to the terrorist attacks of September 11, 2001. Public Opinion Quarterly, 66(3), 418450.

Jacobs, D., Veny, Y., Callier, L., Herman, B., and Descamps, A. (2011). The impact of the conflict in Gaza on antisemitism in Belgium. Patterns of Prejudice, 45(4), 341-360.

Jakobsson, N. and Blom, S. (2014). Did the 2011 terror attack in Norway change citizens' attitudes toward immigrants. International Journal of Public Opinion Research, 26(4), 475-486. 
LaPiere, R. T. (1934). Attitudes vs. actions. Social Forces, 13, 230-237.

Legewie, J. (2013). Terrorist events and attitudes toward immigrants: a natural experiement. American Journal of Sociology, 118, 1199-1245.

Lieberson, S. (1985). Making It Count: The Improvement of Social Research and Theory. University of California Press, Berkeley and Los Angeles.

Nakonezny, P. A., Reddick, R., and Rodgers, J. L. (2004). Did divorce decline after the Oklahoma City bombing? Journal of Marriage and Family, 66(1), 90-100.

Neumark, D. (2012). Detecting discrimination in audit and correspondence studies. Journal of Human Resources, 47(4), 1128-1157.

Noelle-Neumann, E. (2002). Terror in America: assessments of the attacks and their impact in Germany. International Journal of Public Opinion Research, 14(1), 93-98.

Nygård, G. (2011). Education. In K. Henriksen, L. Østby, and D. Ellingsen, editors, Immigration and immigrants 2010, chapter 3, pages 47-76. Statistics Norway, Oslo.

Olsen, B. (2011). Labour. In K. Henriksen, L. Østby, and D. Ellingsen, editors, Immigration and immigrants 2010, chapter 4, pages 77-102. Statistics Norway, Oslo.

Pager, D. (2007). The use of field experiments for studies of employment discrimination: contributions, critiques, and directions for the future. Annals of the American Academy of Political and Social Science, 609, 104133.

Rodgers, J. L., St John, C. A., and Coleman, R. (2005). Did fertility go up after the Oklahoma City bombing? An analysis of births in metropolitan counties in OKlahoma, 1990-1999. Demography, 42(4), 675-692.

Schüller, S. (2016). The effects of $9 / 11$ on attitudes toward immigration and the moderating role of education. Kyklos, 69(4), 604-632.

Sides, J. and Citrin, J. (2007). European opinion about immigration: the role of identities, interests and information. British Journal of Political Science, 37(3), 477-504. 
Sorrentino, R. M. and Vidmar, N. (1974). Impact of events: short- vs. longterm effects of a crisis. Public Opinion Quarterly, 38(2), 271-279.

Traugott, M., Brader, T., Coral, D., Curtin, R., Featherman, D., Groves, R., Hill, M., Jackson, J., Juster, T., Kahn, R., Kennedy, C., Kinder, D., Pennell, B.-E., Shapiro, M., Tessler, M., Weir, D., and Willis, R. (2002). How Americans responded: a study of public reactions to 9/11/01. PS: Political Science and Politics, 35(3), 511-516.

Wollebæk, D., Enjolras, B., Steen-Johnsen, K., and Ødegård, G. (2012). After Utøya: how a high-trust society reacts to terror-trust and civic engagement in the aftermath of July 22. PS: Political Sciences and Politics, 45, 32-37. 